\title{
猛禽類保護と生物多㥞性保全
}

\section{Raptor Conservation and its Relationship to the Biodiversity Conservation of Environment}

山㠃 亨*

Toru YAMAZAKI

猛禽類は生態系の上位種やアンブレラ種として位置づけ られ，環境保護の指標生物として取り扱われることが多い。 また，最近では，開発計画にかかる環境影響評価において， イヌワシ・クマタカ・オオタカの保護がしばしば社会的な 問題となっている。猛禽類が何故, 生態系の保全において, 重大な関心をむって見られ，また生物多様性とどのような 関係があるのかを簡単に紹介したい。

猛禽類は絶滅の危機に瀕している種が多く，イヌワシや クマタカは「絶滅のおそれのある野生動植物の種の保存に 関する法律」の絶滅危惧種，オオ夕カは危急種に指定され ている。猛禽類の多くが法的に保護の対象となっているが, それだけの理由で猛禽類の保護が重要なのではない。猛离 類の保護は, 猛禽類の存在が生態系の安定性や生物の多様 性と密接に関係していることから重要なのである。

\section{1. 猛禽類とは・・・}

猛禽類の特徵は何と言っても他の動物を捕食していると いうことである。このため，猛离類が生息するには慨とな る動物の生存を可能とする植物や生物が安定して生育・生 存している環境がなければ不可能だということになる。こ のことは，猛禽類が生態系において，きわめて不安定な位 置に存在しているということでああり，環境变化の影響を 強く受けやすいことを意味している。

\section{(1) 猛禽類の種類}

猛禽類といってもイヌワシやクマタカのように山岳地帯 に生息するものだけではない。猛禽類の仲間は，DNA 分 類では夕力科（ミサゴ亜科，夕力亜科）・ヘビクイワシ科・ 八ヤブサ科に分類され，昼行性の種類数は世界で 292 種, 日本でも約 30 種が確認されている（その内，16-18 種が国 内で繁殖)。大きさもさまざまで，翼開長（翼を広げた長 さ）がヒメハャブサでは約 $24 \mathrm{~cm}$ しかないのに対し，イヌ ワシでは約 $2 \mathrm{~m}$ ほどああり，最大のコンドルでは $3 \mathrm{~m}$ を越 えるほよ゙大きい（図 1)。この他に，翼の形もグライダー のように板状に長いもの（イヌワシなど）や奴凧のように

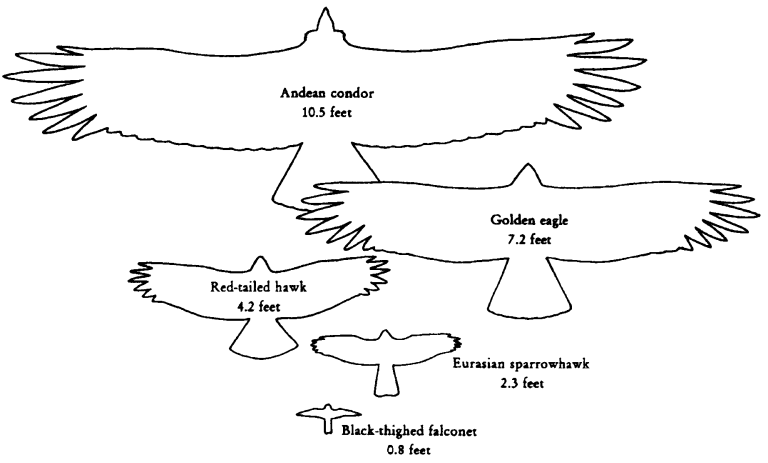

RAPTORS THE BIRDS OF PREY 1996 (Credit: Scott Weidensaul)

図-1 猛离類の大きさ

幅広いもの（クマタカなど），先のとがった三角形をして いるもの（ハヤブサなど）など，生息する環境やハンテイ ング方法に応じてさまざまな形態がある。

猛禽類はそれぞれ，餉とする動物が異なっていたり，た とえ同じ饂であってもハンテイング場所や方法が異なって いるため，300 種ほどの種を維持することができているの である。このことは，猛禽類の種ごとに食物連鎖が存在し ているということであり，猛禽類の 1 種が生息しているこ とが生物の多様性を必ずしも意味するものではない。

(2) 猛禽類の繁殖性

(1)少ない 1 腹卵数

猛禽類の産卵数は少ない。イヌワシは 2 卵のことが多く (1 卵や 3 卵のこともまれにある)，クマ夕力は 1 卵しか産 卵しない。また，才オタカあ $2 \sim 3$ 卵程度である。しかも 大型の猛离類では毎年繁殖することは少なく，日本のイヌ ワシは繁殖成績が良いつがいでも 2 年に 1 回位のことが多

く, 数年に 1 回しか繁殖できないつがいも多い。 (2)幼鳥の高い死亡率と長い寿命

また，うまく繁殖に成功しても，繁殖が可能な年齢にな るまでの死亡率がきわめて高いのが特徴である。図 2 のよ うに，幼鳥の死亡率は八クトウワシが $78.5 \%$ ，八ヤブサ

*クマタカ生態研究グループ 


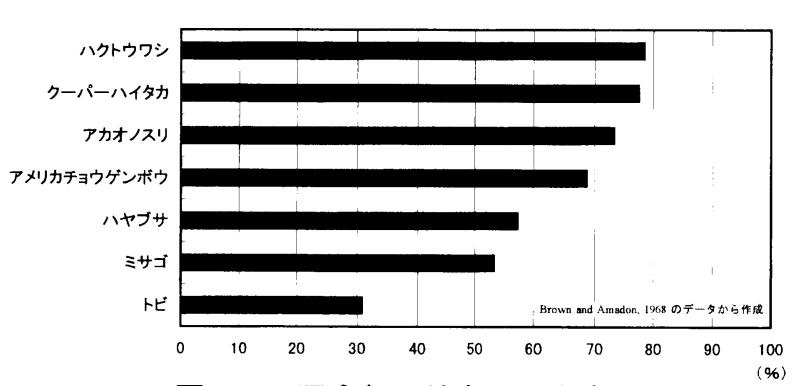

図-2 猛离類の幼鳥の死亡率

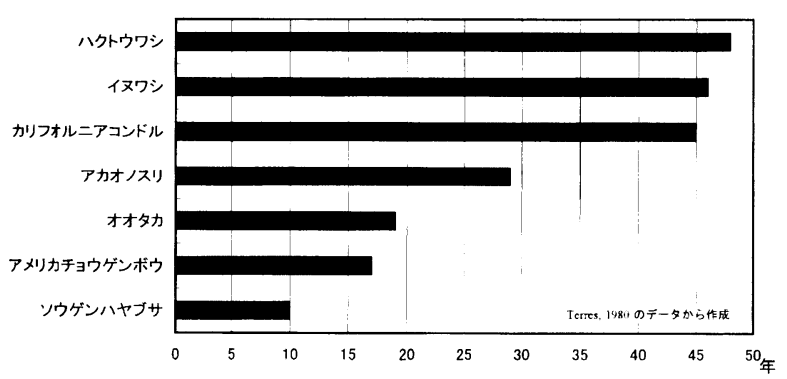

図一 3 猛离類の寿命

が 57.4\%で，ほとんどの種で半数以上が死亡している。 イヌワシはスコットランドでの研究によると繁殖可能な 4 才になるまでに約 $75 \%$ が死亡すると報告されている。私 たちが滋賀県でクマタカの巣立ち雛に発信器や翼帯マーカー を装着して追跡調査した結果でも, 巣立ち後の初めての冬 に約半数が死亡していることが分かり，4才の成鳥になる までには海外の大型猛禽類と同様に $3 / 4$ 程度が死亡する のではないかと思われた。

一方, 猛离類の寿命そのものは長い。図 3 は飼育下での 猛禽類の最長生存記録を示したものである。ハクトウワシ が 48 年, イヌワシが 46 年，オオタカが 19 年である。寿 命は繁殖可能な年齢になるまでの期間と相関性があり，ク マタカはイヌワシと同じく，4 年ほどで繁殖可能になると 思われることから，クマタカも 30 年以上の寿命を持って いるものと推定される。しかし，野外ではハンテイング時 の事故や環境の悪化による餌不足, 環境污染物質の影響等 により，実際の平均寿命がずっと短いことは間違いない。

猛禽類の 1 腹卵数が少ないことは, 猛禽類の寿命が長い ことと関係している。猛离類の繁殖活動の可否は餌動物の 量の影響を大きく受けるため, 猛禽類は後継個体を確保す るのに必要な最低限の数しか産卵しない。巣立ち蚫隹の死亡 率が高いのは，ハンテイング能力が十分でない個体は淘汰 されることにも関係している。そして，何とか繁殖個体群 に参画することができたハンティング能力の高い個体が後 継個体を生産することができるのである。

このような猛昺類の繁殖特性 (戦略) は, 長い長い期間 の生息環境による選抜淘汰の結果であり，これまでにない ようなスピードで自然環境が変化することは，1腹卵数の
少ない猛禽類にとっては死活問題となるのである。

(3) 猛离類の個体数は少ない?

(1)少ない個体数と広い行動範囲

猛昺類は生態系の食物連鎖の頂点に位置するため, 当然, 個体数が少ない。また, 留鳥の大型猛禽類は広い行動圏を 持っている。しかし，この広い行動圏は，1年を通じて生 活することができ，かつ繁殖活動を行うために必要な餉を 確保するのに最低限の面積でああるのだ。

猛离類が繁殖に成功できるかどうかは, 餌動物の個体数 の影響を大きく受ける。䬺動物の個体数が年によって変動 しても, また植生に変化があっても, 数年に一度は繁殖に 成功しなければ後継個体を確保することができない。この ため, 猛离類は行動圏内の環境に変化があっても繁殖活動 が維持できるだけの行動圏面積を有していなければならず, 結果として広い行動圏を占有しているのである。

\section{(2)低い目撃率}

猛禽類のほとんどは繁殖期以外には単独で行動すること が多く，また，獲物に気付かれないように姿を隠している ことも多いため, 猛禽類を目撃する頻度はきわめて低い。 さらにイヌワシやクマタカのように大型の猛禽類では, 毎 日ハンテイングしているとは限らない。猛禽類のイメージ として, 常に飛行し, ハンテイングを行っているように思 われていることが多いが, 決してそうではない。獲物を探 し，捕らえるということは，かなりのエネルギーを必要と するものであり，ハンテイングに成功した後は，エネルギー 消費を抑制するため，1日のほとんどを止まったままで過 ごしていることも多く，このことも目撃率を低くしている。 (4) 猛禽類と環境変化

これまで述べてきたように，猛禽類は生態系の食物連鎖 の頂点に位置するため, 環境変化の影響を強く受けやすい 生物である。

(1)餌動物の個体数の影響

猛禽類のハンテイング成功率は一般に思われているほど 高くない。従って, 餌動物の個体数が減少すると, 確実に 餌を確保することが困難となる。猛禽類は餌動物が豊富で, 雌が栄養を十分に確保できた場合にのみ, 繁殖行動を開始 することが多い。従って餌動物の個体数が減少すると, 産 卵できないこととなり，ひいては後継個体の不足を招く。

北米ではイヌワシの餌動物であるジリス, ジャックラビッ トの個体数の年変動が激しく，このような地域に生息する イヌワシは餉が豊富な年には 3 羽の雛を巣立たせることが あるが，逆に䬺が不足する年にはほとんど繁殖に成功でき ない。しかし，クマタカのように森林に生息する猛禽類は 森林内の餌動物の個体数が比較的安定しているため, 個体 群を維持するだけの最低限の卵しか産卵しないように適応 してきている。従って, 森林構造の変化によって生物生産 量が減少することは，繁殖活動が行えなくなることを意味 


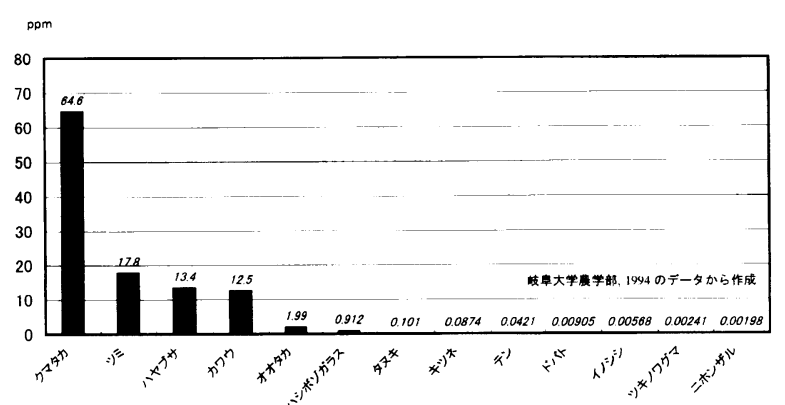

図一４野生動物中の PCB 濃度

し，種の維持にとってきわめて危機的な状態となる。 (2)生物濃縮による環境污染物質の蓄積

猛禽類は食物連鎖の頂点に位置するため，環境污染物質 が生物濃縮によって高濃度に体内に蓄積しやすく, 環境污 染の影響をいち早く, また強く受けやすい。㞳阜大学 （1994）による野生動物の肝臟または脂肪組織中の PCB 濃 度調査結果では, クマタカが $64.6 \mathrm{ppm}$ で最も高く, 次い でッミが $17.8 \mathrm{ppm}$ であった。猛离類はすべて $1 \mathrm{ppm}$ 以上 であり, 猛禽類以外ではカワゥが $12.5 \mathrm{ppm}$ と高い。カワ ウは魚を捕食しており, 水系の食物連鎖の頂点に位置して いるため, 猛禽類と同様に環境污染物質が体内に蓄積しや すいのではないかと思われる。

また, 猛禽類は寿命が長いことから, 環境污染のレベル が低くても, 分解性の低い有機塩素化合物などは長期間に わたる摂取によって体内に高濃度に蓄積されることとなり, 繁殖機能障害や免疫不全などを引き起こしやすい。

\section{2. 日本の猛离類}

(1) 猛禽類と生物の多様性

日本では，丘陵地から山岳地帯にかけて，サシバ，ツミ， 八イタカ, オオ夕カ, 八チクマ, ノスリ, クマタカ, イヌ ワシが生息し，繁殖する。地域によっては，2 種以上の猛 禽類が同じ地区に生息していることもある。そのような地 区は複数種の猛禽類の生息を可能とするほど多種類の餌動 物が生息し，またハンテイングを可能とする多様な植生が 存在しているということが言える。

一方, 海岸部で渡り鳥を主たる慨としている八ヤブサな ぞは直接的にはその地域の生態系の豊かさや多様性とは関 係していないのかむ知れない。また，最近では都市部や都 市近郊に增加しているドバトやキジバト，ムクドリなどを 餌とするハヤブサやオオタカが出現し始め，今まで記録の なかった都市部でも繁殖するようになった例が報告されて いる。ある意味では, 都市部に猛禽類が定着することで新 たな生態系の食物連鎖が確立されてきているとも言える。

(2) イヌワシ・クマタカ・オオタカ

それでは, イヌワシ・クマタカ・オオタカがどのように 日本の山岳森林帯の自然環境に適応し, 棲み分けているの
表－1 イヌワシ・クマタカ・オオタカの行動特性

\begin{tabular}{|c|c|c|c|}
\hline & イメワシ & クマタカ & オオタカ \\
\hline おもな䁒㽖物 & ハウサギ・ヤマドリ・ヘビ & さまざまな中小轵物 & おもに小型〜中型の頪 \\
\hline ハンテイングエリア & 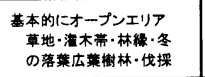 & 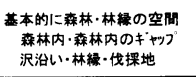 & 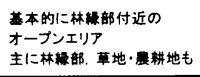 \\
\hline \multirow[t]{2}{*}{ ハンテイング方法 } & 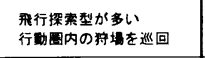 & $\begin{array}{l}\text { 止まって待つ型が多い } \\
\text { 1ヶ所の狩徣で粘る }\end{array}$ & 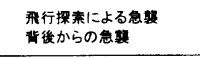 \\
\hline & 単独・ベアハンテイング & 単 独 & 単独 \\
\hline テリトリー & 狩堨を含めたベアなわばり & 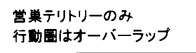 & 営耖テリトリー \\
\hline つがい関係 & 周年つかい闌係を潅持 & 単独(箱期につがい形成) & 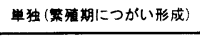 \\
\hline デイスプレー & 我行デイスルレーが主体 & 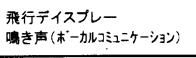 & 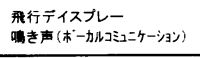 \\
\hline 行的图面积 & 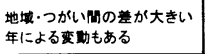 & $\begin{array}{l}\text { ほとんどー定 } \\
\text { 年によるる夜趿もあまりない }\end{array}$ & 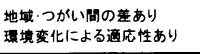 \\
\hline
\end{tabular}

かを紹介したい（表 1)。

(1)生息環境

イヌワシは北半球の高緯度地域に広く分布し, 草地や低 潅木が分布する地域や山岳地帯に生息している。日本では 北海道から九州まで分布しているが，近畿地方以北から東 北地方が主たる生息域であり，落葉広葉樹林の少ない四国 や九州には数つがいが生息しているだけである。イヌワシ は主として, 低潅木地帯や草付き場, 森林に隣接した崩壊 地などのオープンエリアでハンティングを行うため，この ような環境が存在する地域でないと生息できないからであ る。東北地方や北陸地方に多く生息しているのは, 草地や 低潅木地が比較的多いことの他に, 冬の落葉期には林床部 が見え，ハンテイング場所として利用することが可能な落 葉広葉樹林が広範囲に広がっているためである。

これに対して, クマタカはスリランカ, インドシナ半島, 中国東南部など東南アジアの山岳森林地帯に分布し, 日本 は分布域のほぼ北限に位置する。日本では九州から北海道 まで，針葉樹林や広葉樹林に限らず，餌となる動物が豊富 に生息している森林のある山岳地带に広く生息している。 クマタカはイヌワシよりも一回り小さいものの, 体長が約 70 80 cm あある大型猛禽類だが，翼の幅が広く，小回りの きく飛行が可能で, 森林内に入っていくことができるから である。

オオタカあ全国に分布し, イヌワシやクマタカより少し 標高の低い山地帯や丘陵地に生息していることが多い。林 縁部のオープンエリアが主なハンテイング場所であるが, 草地や農耕地のような開けた空間でむハンテイングを行う ことがある。営巣林はアカマッ林が多く, 高木層は密だが 亜高木層が疎で，林内に空間がある林が多く利用される。 (2)行動圈

イヌワシの行動圏はきわめて広く, 1 つがいの行動圏は 21 119kn (平均約 $60 \mathrm{~km}^{2}$ ) であるが，200 $\mathrm{km}^{2}$ 越えること あある。地域による差が大きいのは，日本ではイヌワシが ハンテイングを行うことが可能な場所が少なく, 山岳地帯 に散在していることが原因しているのかも知れない。 
これに対して, クマタカは北限の北海道で分布密度の低 い地域があるという報告があるものの, 全国の山岳森林地 帯に約 25-30km² 1 つがいの割合でほぼ均一に分布してい る。クマタカは森林内でハンテイングを行うことが可能な ため, その森林内に餌となる中小動物が豊富であり, 営巣 可能な大木が存在していれば, 植生に関係なく, 隣接つが いが一定の巣間距離を保って生息することができるのであ る。

オオタカの行動圏は栃木県でのラジオテレメトリー法に よるオスの調査結果によると, 繁殖前期 : 7.3-12 $\mathrm{km}^{2}$, 巣内 育煼期 : 約 9-10kn, 巣外育㮲期 : 約 $6-8 \mathrm{~km}^{2}$, 非繁殖期 : 約 10-11 kñ である。また，北海道の調査結果ではオスが平 均 $12 \mathrm{~km}^{2}, x$ メが平均 $27 \mathrm{~km}^{2}$ と報告されており，才オタカの 行動圏はクマタカに比べてやや狭いものと思われる。しか し，オオタカは山岳地帯に生息するものから都市近郊の平 野部に生息するあのまで生息環境に幅があることから，今 後, 調査が進めば行動圏面積の地域ごとの差はさらに大き くなるものと思われる。

(3)食性

イヌワシはノウサギ，ヤマドリ，アオダイショウなどの

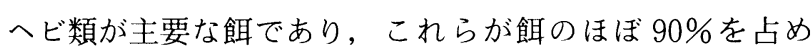
ており，全国的にも同じ傾向が見られる（日本イヌワシ研 究会の全国規模の調査結果)。もともとイヌワシは自然草 地や低潅木地帯で中小動物を捕食しており，日本ではこの ような開けた場所が少なく，ハンティングを行うことがで きる場所が限られているため，餌となる動物の種類も限定 されるのではないかと思われる。

これに対し，クマタカはイヌワシと同様にノウサギ，ヤ マドリ，へビを多く捕食するが，これ以外にあアナグマ, タヌキ, テン, イタチ, ムササビ, 二ホンリス, ヒミズ, カケス, アオバト, ヒヨドリ，カラス，ホオジロなど, さ まざまな中小動物を捕食している。また，クマタカの食性 は地域差が大きいということも特徵である。つまり, クマ 夕力は森林内に生息するさまざまな中小動物を捕食してい るため，生息地の動物相を反映した食性となるのである。 また，クマタカのハンテイング方法はイヌワシと異なり， 獲物が出現するのをじっと止まって待つというタイプが多 い。

オオタカの餌はドバト・ハト類が多く，その他にはカケ ス,ッグミ，ムクドリ，ヒヨドリなど個体数の多い小型〜 中型の鳥類が主要な餌となっている。ハンテイング場所は 林縁部や開けた場所で, 獲物を襲う方法は獲物を直接, 飛 行して追跡したり，背後から忍び寄って不意打ちをかける ことが多い。オオタカは空中で鳥類を追跡して捕らえるこ とが得意なため, 都市部や水辺などでも獲物となる鳥類が 生息していれば生活することができる。最近では都市近郊 部にドバト，ムクドリ，ヒヨドリ，キジバトが多く生息す
る場所が増え, その近くに営巣可能なスギ林やマッ林など があれば繁殖も可能となり, オオタカはこのような場所で 生息域を拡大している。

このように 3 種はそれぞれ異なる食性や行動特性を有し, 異なる生息環境を利用しているため, 同一地区に 3 種が生 息することも可能となり, その地区は自然環境や生物相が 多様性に富んでいるとも言えるのである。

\section{3. 環境指標生物としての猛禽類保護}

最近, 開発計画と猛禽類保護の問題がニュースに取り上 げられることが多い。このためにイヌワシ, クマタカ, オ オタカの存在が一般に知られるようになったと言っても過 言ではない。ダム建設や大規模道路敷設などに関連してい ることが多く, しばしば開発か猛禽類保護かの単純な構図 で問題提起されている。しかし，このことは間違いである。 これまでに述べてきたとおり, 猛禽類は生態系の変化を最 あ受けやすい生物種であり, 猛离類の保護はその生息を可 能とする生物相の豊かさと安定性を維持することであるこ とを認識しなければならない。つまり, 猛禽類を保護する ということは猛离類の生息を可能とする生態系の生物を育 む機能を維持することであり, それは私たち人間の生存に とっても必要な自然環境を保全することになるのである。 猛禽類保護は人間を含めた生物多様性の保護でああり, 決 して適正な開発と対立することはないはずなのである。

従って, 環境影響評価調査においては, 対象となる猛禽 類の生態を十分に理解し, 開発計画による環境改変がその 猛昺類の生活を維持する生態系の機能によ゙のような影響を 与えるのかを科学的に判断できるデー夕を取らなければな らない。また，猛禽類は自然環境の変化に対応して生息し 得る最低限の面積を行動圏としていることから, 単に 1 年 間だけの調査結果でその影響を判断してはならない。とく にイヌワシやクマタカのように数年に 1 回しか繁殖しない ような種では, 少なくとあ 3 年間以上にわたって彼らがど のように生息環境を利用しているのかを見極めないといけ ない。さらに, 日本の猛离類のおかれている現状はすでに 環境変化の影響を大きく受け, きわめて厳しい状態にある ことも認識しておかねばならない。イヌワシやクマタカの 繁殖成功率は 1985 年頃から急激に低下し, 個体群を維持 できるレベルを大きく下回るほどになっている。これは, 彼らの生息環境がスギ・ヒノキの大規模な植林, 開発によ る広範な森林の消失, 環境污染など, 種の維持に対応可能 な自然環境の変化を越える深刻な悪化状態にあるというこ とである。

実際に猛舍類の保護を実現できるのは, 開発計画など自 然環境の改変を担っている人たちであることも事実であり, これらの人々が猛禽類保護と開発が矛盾するあのではない という認識と自負を持つことが大切である。 